\title{
Review p53 and its isoforms in cancer
}

\author{
J-C Bourdon*,I \\ 'Inserm European Associated Laboratory, Department of Surgery and Molecular Oncology, University of Dundee, Inserm U858, CR-UK Cell \\ Transformation Research Group, Dundee, UK
}

p53, p63 and p73 are members of the p53 gene family involved in development, differentiation and response to cellular stress. p53 gene is a transcription factor essential for the prevention of cancer formation. The p53 pathway is ubiquitously lost in human cancer either by $\mathrm{p} 53$ gene mutation (60\% of cancers) or by lost of cell signalling upstream and downstream of p53 in the remaining cancers expressing WTp53 gene. As p53 pathway inactivation is a common denominator to all cancers, the understanding of p53 tumour suppressor activity is likely to bring us closer to cancer therapy. However, despite all the experimental evidences showing the importance of p53 in preventing carcinogenesis, it is difficult in clinical studies to link p53 status to cancer treatment and clinical outcome. The recent discovery that p53 gene encodes for nine different p53 proteins (isoforms) may have a profound impact on our understanding of p53 tumour suppressor activity. Studies in several tumour types have shown that the nine different p53 isoforms are abnormally expressed in tumour tissues compared to normal cells. p53 protein isoforms modulate p53 transcriptional activity and cell fate outcome in response to stress. Regulation of p53 function in normal and tumour tissues in man is likely to be more complex than has been hitherto appreciated. Therefore, the tumour p53 status needs to be determined more accurately by integrating p 53 isoform expression, functional p53 mutation analysis and a panel of antibodies specific of p53 and of its target genes.

British Journal of Cancer (2007) 97, 277-282. doi: I0.1038/sj.bjc.6603886 www.bjcancer.com

Published online 17 July 2007

(c) 2007 Cancer Research UK

Keywords: splice; promoter; tumour; transcription; apoptosis; cell cycle

The response to cellular damage is complex involving the recognition of the damages and repair of the lesions, in particular, DNA damages to minimise the risk of genetic instability. Therefore, mutations or alterations of protein expression involved in this process predispose to genome instability, cancer and other pathologies (Kops et al, 2005). A central player in protecting the integrity of the genome is p53. The importance of its role is exemplified by the facts that p53 activity is ubiquitously lost in human cancer either by $\mathrm{p} 53$ protein inactivation or by $p 53$ gene mutation (for a review, see Iwakuma and Lozano, 2007; Lozano, 2007; Petitjean et al, 2007a; Vousden and Lane, 2007).

p53 protein is expressed at low levels under unperturbed conditions. However, the p53 pathway is activated by any cellular stresses that alter the normal cell-cycle progression or can induce mutations of the genome leading to the transformation of a normal cell into a cancerous cell. Depending on the tissue-type and the extend of the damage, activated p53 protein either stops the cell cycle to repair the lesions or switches 'on' the programmed cell death pathways (apoptosis), forcing the damaged cells to 'commit suicide'. The p53 protein prevents the multiplication of damaged cells that are more likely to contain mutations and exhibit abnormal cellular growth than undamaged cells. Hence, p53 protein is the guardian of the genome preventing cancer formation (Lane, 1992).

*Correspondence: J-C Bourdon; E-mail: j.bourdon@dundee.ac.uk Received I5 March 2007; revised 5 June 2007; accepted 22 June 2007; published online 17 July 2007
The mechanisms by which p53 accomplishes its tumour suppressor activity are still not completely understood. The bestdescribed mechanism is its ability to modulate gene expression. p53 is a transcription factor that binds directly and specifically as a tetramer to target sequences of DNA (p53-responsive elements (p53RE)) (El-Deiry et al, 1992; Funk et al, 1992; Bourdon et al, 1997). The ability of p53 to modulate gene expression is required for its tumour suppressor activity. Identification of the cyclindependent kinase inhibitor Waf as a p53-responsive gene, helps to explain how p53 can induce cell-cycle arrest (El-Deiry et al, 1993; Harper et al, 1993). Recently, several p53-inducible genes that encode for proteins with apoptotic potential have been identified (Chipuk and Green, 2006). However, the tumour suppressor p53 can trigger cell death independently of its transcriptional activity through subcellular translocation and activation of proapoptotic Bcl-2 family members (Moll et al, 2005).

\section{HUMAN p63 AND p73 ISOFORMS}

Two p53-related genes, p63 and p73, were identified in 1997 (Kaghad et al, 1997; Yang et al, 1998). The high level of sequence similarity in the DNA-binding domain between p53 protein family members allows p63 and p73 to transactivate p53-responsive genes causing cell-cycle arrest and apoptosis. However, p53, p63 and p73 proteins are not entirely functionally redundant as each p53-family transgenic knockout mice develop distinct phenotypes, illustrating that $p 53, p 63$ and $p 73$ have specific biological functions (for a review, see Murray-Zmijewski et al, 2006). 


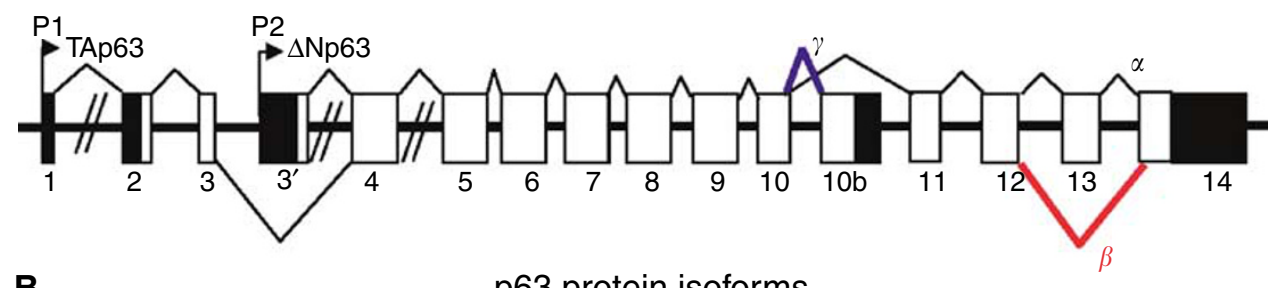

B

p63 protein isoforms

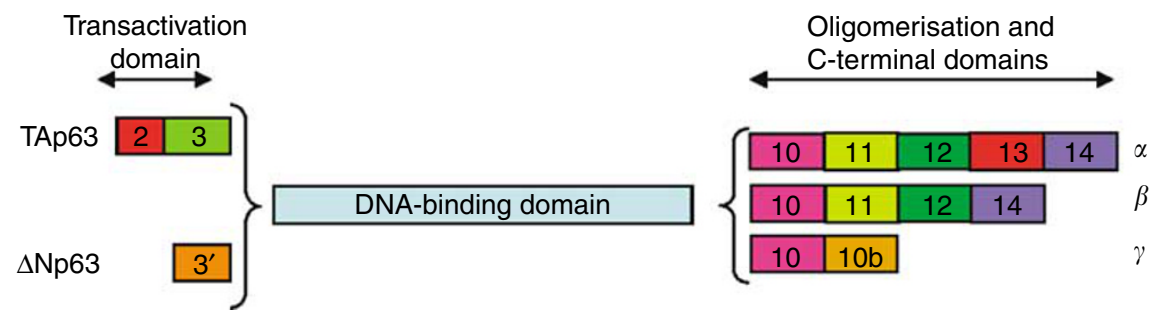

Figure I Human p63. (A) Schema of the human p63 gene structure: alternative splicing $(\alpha, \beta, \gamma)$ and alternative promoters (PI and P2) are indicated. (B) p63 protein isoforms: TAp63 proteins encoded from promoter PI contain the conserved $\mathrm{N}$-terminal domain (Fxx $\psi \mathrm{W}$ ) of transactivation (TA). $\Delta \mathrm{Np} 63$ proteins encoded from promoter P2 are amino-truncated proteins containing an N-terminal domain different from TAp63 proteins. Numbers indicate the exons encoding p63 protein isoforms.

We recently published that the $p 53$ gene family (p53/p63/p73) has a dual gene structure conserved in Drosophila, zebrafish and man (Bourdon et al, 2005; Chen et al, 2005). Like most of the genes in the human genome (Stamm et al, 2005), p53 gene family members express multiple mRNA variants due to multiple splicing and alternative promoters. Hence, $p 53$ gene family members express different forms of $\mathrm{p} 53$ protein containing different domain of the protein (isoforms).

The human and mouse p63 genes express at least three alternatively spliced C-terminal isoforms $(\alpha, \beta, \gamma)$ and can be transcribed from an alternative promoter located in the intron 3 (Figure 1A). The transactivating isoforms (TAp63) are generated by the promoter upstream of exon-1, whereas the alternative promoter in intron 3 leads to the expression of $\mathrm{N}$-terminaltruncated $\mathrm{p} 63$ isoforms $(\Delta \mathrm{Np} 63)$ containing a different $\mathrm{N}$-terminal domain. Altogether, the $p 63$ gene expresses at least six mRNA variants which encode for six different p63 protein isoforms (TAp63 $\alpha$, TAp63 $\beta$, TAp63 $\gamma, \Delta \mathrm{Np} 63 \alpha, \Delta \mathrm{Np} 63 \beta$ and $\Delta \mathrm{Np} 63 \gamma$ ). Although $\Delta \mathrm{Np} 63$ isoforms lack the transactivation domain present in TAp63 isoform, they can transactivate through a different transactivation domain present in their distinct $\mathrm{N}$-terminal end (Helton et al, 2006) (Figure 1B). p63 isoforms are able to bind to DNA through p53RE and p63RE to regulate transcription of target genes involved in differentiation, cell-cycle arrest or apoptosis (Murray-Zmijewski et al, 2006; Stiewe, 2007). Genetic experiments on mice have shown that p63 is essential for epidermal morphogenesis and limb development. p63-null animals do not survive beyond a few days after birth, show craniofacial malformations, limb truncations and fail to develop skin and other epithelial tissues (Mills et al, 1999).

Like $p 63$, the $p 73$ gene can be transcribed from an alternative promoter located in the intron 3 (Figure 2A). The $p 73$ gene expresses at least seven alternatively spliced C-terminal isoforms $(\alpha, \beta, \gamma, \Delta, \varepsilon, \zeta, \eta)$ and at least four alternatively spliced $\mathrm{N}$-terminal isoforms, which contain different parts of the transactivation domain. Altogether, the $p 73$ gene expresses at least 35 mRNA variants, which can encode theoretically 29 different p73 protein isoforms (Figure 2B). p73 isoforms encoded by alternatively spliced exon2 and/or exon-3 mRNA variants are initiated at different ATG and contain therefore different part of the $\mathrm{N}$ terminal domain, suggesting that they can have distinct protein interactions and specific activities. p73 isoforms are able to bind specically to DNA through p53RE and p73RE and activate transcription of target genes. Like p53, such activation can induce cell-cycle arrest or apoptosis (Murray-Zmijewski et al, 2006; Stiewe, 2007). Mice, functionally decient for all p73 isoforms, exhibited profound defects, including hippocampal dysgenesis, hydro-cephalus, chronic infections and inammation, as well as abnormalities in pheromone sensory pathways; however, did not show any increase susceptibility to cancer (Yang et al, 2000).

\section{HUMAN p53 ISOFORMS}

We recently established that human $p 53$ gene has indeed a dual gene structure similar to $p 73$ and $p 63$ genes (Bourdon et al, 2005). p53 gene transcription can be initiated in normal human tissue from two distinct sites upstream of exon 1 and from an internal promoter located in intron 4 (Figure $3 \mathrm{~A}$ ). The alternative promoter leads to the expression of an N-terminally truncated p53 protein initiated at codon $133(\Delta 133 \mathrm{p} 53)$. The intron 9 can be alternatively spliced to produce three isoforms: p53, p53 $\beta$ (identical to p53i9) and $\mathrm{p} 53 \gamma$, where the $\mathrm{p} 53 \beta$ and $\mathrm{p} 53 \gamma$ isoforms lack the oligomerisation domain. Therefore, the human $p 53$ gene can encode at least nine different $\mathrm{p} 53$ protein isoforms, $\mathrm{p} 53, \mathrm{p} 53 \beta, \mathrm{p} 53 \gamma, \Delta 133 \mathrm{p} 53$, $\Delta 133 \mathrm{p} 53 \beta$ and $\Delta 133 \mathrm{p} 53 \gamma$ due to alternative splicing of the intron 9 and usage of the alternative promoter in intron 4 , and also $\Delta 40 \mathrm{p} 53$, $\Delta 40 \mathrm{p} 53 \beta, \Delta 40 \mathrm{p} 53 \gamma$ due to alternative splicing of the intron 9 and alternative initiation of translation or alternative splicing of the intron 2 (Ghosh et al, 2004) (Figure 3). p53 variant mRNA are expressed in several normal human tissues in a tissue-dependent manner, indicating the internal promoter and the alternative splicing of $p 53$ can be regulated. Moreover, the tissue-specific expression of the p53 isoforms could explain the tissue-specific regulation of p53 transcriptional activity in responses to stresses such as ionising radiation, $\mathrm{UV}, \mathrm{pH}$ and hypoxia. Thus, the liver induces $p 21$ and cell-cycle arrest in a p53-dependent manner, whereas the spleen and thymus induce a massive p53-dependent apoptosis in response to the same dose of ionising radiation. (Midgley et al, 1995; Bouvard et al, 2000; Fei et al, 2002).

We have shown using commonly available p53 antibodies that endogenous p53 isoforms are expressed at the protein level. However, such antibodies cannot identify specifically the p53 isoforms. It is only by raising a specific anti-p $53 \beta$ antibody that we 


\section{A}

Human p73 gene structure

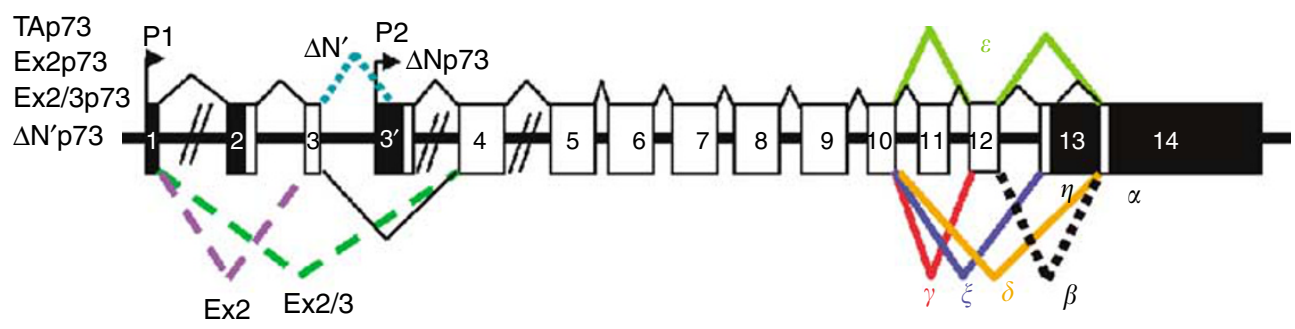

B

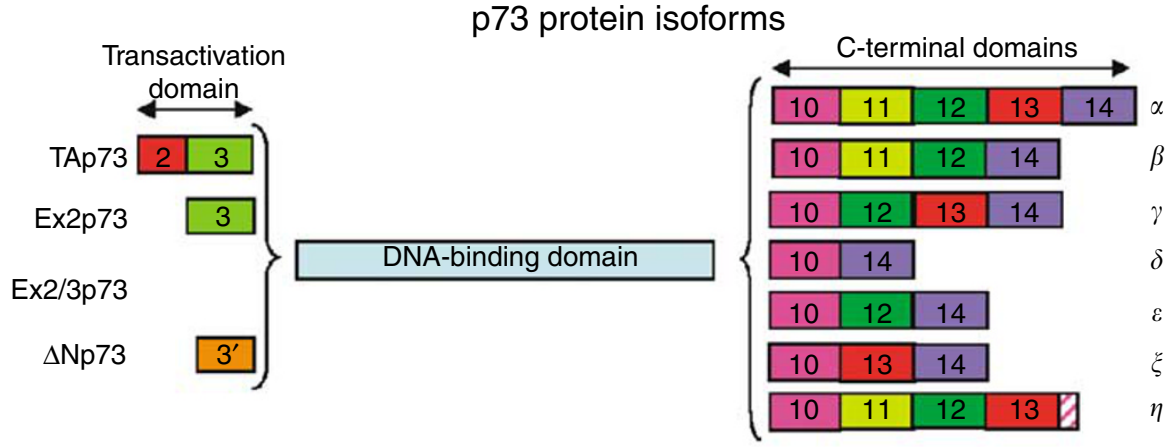

$\Delta \mathrm{N}^{\prime} \mathrm{p} 73$

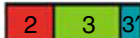

Figure 2 Human $\mathrm{p} 73$. (A) Schema of the human $\mathrm{p} 73$ gene structure: alternative splicing $(\alpha, \beta, \gamma, \zeta, \Delta, \varepsilon, \eta)$ and alternative promoters (PI and P2) are indicated. (B) p73 protein isoforms: TAp73 proteins encoded from promoter PI contain the conserved $\mathrm{N}$-terminal domain ( $\mathrm{F} \times \times \times \mathrm{W}$ ) of transactivation (TA). Ex2p73 proteins are due to alternative splicing of exon 2. They have lost the conserved $\mathrm{N}$-terminal domain (FxxiW) of transactivation (TA), but still contain part of the transactivation domain (Exon-3). Ex2/3p73 proteins are due to alternative splicing of exons 2 and 3 . They have entirely lost the TA domain and are initiated from exon 4. To our knowledge, the protein encoded by $\Delta N^{\prime} p 73$ mRNA has not been described. $\Delta N^{\prime}$ 'p 73 variant is often overexpressed at the mRNA level in tumours. $\Delta N^{\prime} p 73$ is due to alternative splicing of exon $3^{\prime}$ contained in intron 3 . Theoretically, $\Delta N^{\prime} p 73$ mRNA would encode either for a short p73 protein or p73 protein isoforms identical to $\Delta \mathrm{Np} 73 . \Delta \mathrm{N}$ 'p73 mRNA contains the normal initiation site of translation in exon 2 (ATG in perfect kozak sequence) and a stop codon in exon-3'. Therefore, it could encode for a short p73 protein composed only of the transactivation domain $\left(\mathrm{F} \times x \psi \mathrm{W}\right.$ ). It is possible that translation of $\Delta \mathrm{N}^{\prime} \mathrm{p} 73 \mathrm{mRNA}$ is initiated from the third ATG available present in exon $3^{\prime}$ and leading to $\mathrm{p} 73$ protein identical to $\Delta \mathrm{Np} 73$ protein isoforms. $\Delta \mathrm{Np} 73$ proteins encoded from promoter $\mathrm{P} 2$ are amino-truncated proteins containing an $\mathrm{N}$-terminal domain different from TAp73 proteins. Numbers indicate the exons encoding p73 protein isoforms.

demonstrated expression of the endogenous $\mathrm{p} 53 \beta$ and $\Delta 133 \mathrm{p} 53 \beta$ protein isoforms. This implies that $\mathrm{p} 53 \gamma, \Delta 133 \mathrm{p} 53 \gamma$ and $\Delta 133 \mathrm{p} 53$ are expressed at the protein level. P53 isoforms have different subcellular localisations, suggesting that they can have distinct activities. Like full-length p53, $\Delta 133 \mathrm{p} 53$ and $\mathrm{p} 53 \beta$ are localised mainly in the nucleus with a minor staining in the cytoplasm. In most cells, $\mathrm{p} 53 \gamma$ is localised in the nucleus, but can be localised in the cytoplasm in some cells, suggesting that p53 $\gamma$ could be shuttling between the nucleus and the cytoplasm. In most cells, $\Delta 133 \mathrm{p} 53 \beta$ protein is localised in the nucleus and the cytoplasm, but can form in $10 \%$ of cells foci in the nucleus that are different from nucleoli. Contrary to $\Delta 133 \mathrm{p} 53 \beta, \Delta 133 \mathrm{p} 53 \gamma$ is localised only in the cytoplasm, indicating that the C-terminal amino acids ( $\beta$ and $\gamma)$ can modify the subcellular localisation of these isoforms (Bourdon et al, 2005).

Interestingly, the dual gene structure of the $p 53$ gene is conserved in human, Drosophila (Bourdon et al, 2005), mouse (Bourdon, unpublished data) and zebrafish (Chen et al, 2005), whereas the alternative splicing is species-specific. It suggests an unforeseen complex regulation that may play a major role in controlling p53 activity. Like p63 or p73 isoforms, p53 isoforms can have distinct biochemical activities.

$\mathrm{p} 53 \beta$ binds preferentially the $\mathrm{p} 53$-responsive promoters $\mathrm{p} 21$ and Bax rather than $\mathrm{Mdm} 2$, whereas p53 binds preferentially to $\mathrm{Mdm} 2$ and $\mathrm{p} 21$ rather than Bax promoters. $\mathrm{p} 53 \beta$ can form a protein complex with p53 and can specifically enhance p53 transcriptional activity at the Bax promoter in response to cellular stress, whereas it has no effect on p53 activity in absence of stress (Bourdon et al, 2005). Co-transfection of $\mathrm{p} 53$ with $\mathrm{p} 53 \beta$ increases slightly $\mathrm{p} 53-$ mediated apoptosis, whereas co-transfection of p53 with $\Delta 133 \mathrm{p} 53$ strongly inhibits p53-mediated apoptosis in a dose-dependent manner. This indicates that wild-type p53 activity may be modulated in the presence of p53 isoforms, and thus that regulation of $\mathrm{p} 53$ function in normal and tumour tissues in human is likely to be more complex than has been hitherto appreciated. Moreover, each p53 protein isoform may have specific biological activities independent of full-length p53. This may explain how p53 can be involved in the regulation of so many biological functions (i.e. cell-cycle arrest, apoptosis, differentiation, replication, DNA repair, meiosis, mitosis, etc...).

Deregulation of p53 isoforms expression may play a role early in tumour formation, as attenuation of the WT p53 response would render the cells more susceptible to further genetic damage and therefore to neoplastic transformation and tumour progression. Tumours with abnormal p53 isoform expression would have a predicted phenotype of WT p53 by sequence but compromised p53 activity. Such hypothesis is consistent with experimental evidences showing abnormal expression of p53 isoforms in head and neck, acute myeloid leukaemia (AML) and breast tumours (Bourdon et al, 2005; Anensen et al, 2006; Boldrup et al, 2007). Whereas only $25 \%$ of breast tumours express mutant p53, p53 $\beta$ and p53 $\gamma$ expressions are frequently lost $(60 \%)$ and $\Delta 133$ p53 is frequently overexpressed in breast tumours. The abnormal p53 isoforms expression can therefore account for loss of p53 tumour suppressor activity in breast tumour. In AML, where $p 53$ gene is mutated only in $10 \%$ of the cases, abnormal p53 isoform expression at the mRNA and protein levels has been reported (Anensen et al, 2006). The authors studied p53 isoform expression 
A Human p53 gene structure

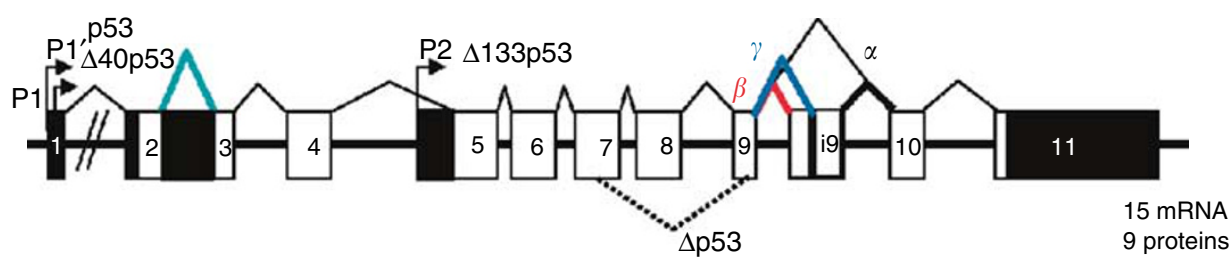

B

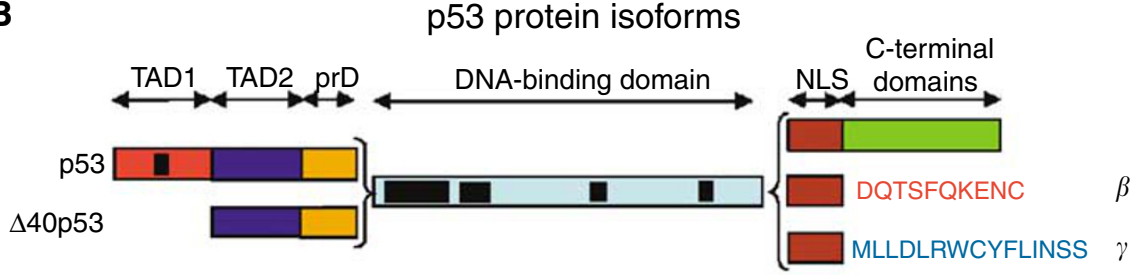

$\Delta 133 p 53$

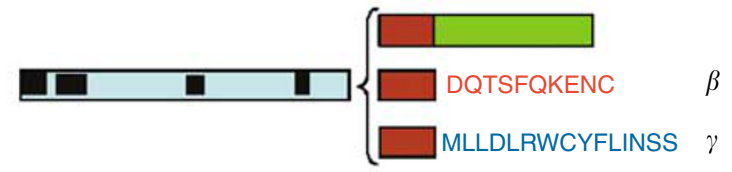

$\Delta \mathrm{p} 53$

Figure 3 Human p53. (A) Schema of the human $p 53$ gene structure: Alternative splicing $(\alpha, \beta, \gamma)$ and alternative promoters (PI, PI' and P2) are indicated. p53 protein isoforms: (B) p53, p53 $\beta$ and $\mathrm{p} 53 \gamma$ proteins encoded from $\mathrm{Pl}$ or $\mathrm{PI}$ ' promoters contain the conserved $\mathrm{N}$-terminal domain ( $\mathrm{F} \times \mathrm{x} / \mathrm{W}$ ) of transactivation (TA). $\Delta$ I33p53 isoforms encoded from promoter P2 are amino-truncated proteins deleted of the entire TA domain and deleted of part of the DNA-binding domain. Translation is initiated at ATG-133. $\Delta 40 \mathrm{p} 53$ protein isoforms encoded from PI or PI' promoters are amino-truncated proteins due to alternative splicing of exon 2 and/or alternative initiation of translation at ATG-40). $\Delta 40$ p53 protein isoform have lost the conserved N-terminal domain of transactivation ( $\mathrm{F} \times \times \psi \mathrm{W}$ ), but still contain part of the transactivation domain. $\Delta \mathrm{p} 53$ protein isoform is due to noncanonical alternative splicing between the exon 7 and $9 . \Delta p 53$ has lost 66 residues including the highly conserved domain $\vee$ of the DNA-binding domain. The isoforms $\Delta p 53 \beta, \Delta p 53 \gamma$, $\Delta 40 \Delta \mathrm{p} 53, \Delta 40 \Delta \mathrm{p} 53 \beta, \Delta 40 \Delta \mathrm{p} 53 \gamma, \Delta|33 \Delta \mathrm{p} 53, \Delta| 33 \Delta \mathrm{p} 53 \beta$ and $\Delta \mid 33 \Delta \mathrm{p} 53 \gamma$ should theoretically be generated.

after chemotherapy in patients using RT-PCR and two-dimensional immunoblot. They reported a rapid shift within $4 \mathrm{~h}$ after chemotherapy from a shorter p53 protein isoform toward fulllength p53 protein expression in AML patient, indicating that expression of $\mathrm{p} 53$ protein isoform could be modulated in vivo in response to chemotherapy.

This strongly suggests that the differential expression of $\mathrm{p} 53$ isoforms could disrupt the p53 response and contribute to tumour formation (Anensen et al, 2006). Moreover, it may provide some explanation to the difficulties in many clinical studies to link p53 status to the biological properties and drug sensitivity of human cancers as p53 status is determined either by sequencing and/or immunohistochemistry.

\section{$\Delta$ p53 ISOFORMS}

It has recently been reported the intra-exons splicing of the exons 7 to 9 of $p 53$, which leads to a p53 isoform deleted of the conserved box $\mathrm{V}$ in the DNA-binding domain ( $\Delta \mathrm{p} 53)$ (Rohaly et al, 2005). This noncanonical splicing is not consistent with any known rules of splicing, which are strictly conserved through eukaryotes (from yeast to human) (Stamm et al, 2005). $\Delta$ p53 mRNA was isolated after reverse transcription at $37^{\circ} \mathrm{C}$ using MMLV reverse transcriptase. Based on our experience, such conditions give rise to cDNA with noncanonical intra-exons splicing after RT-PCR amplification probably because mRNA stem-loop structures are not destroyed at $37^{\circ} \mathrm{C}$. As we perform reverse transcription at $45^{\circ} \mathrm{C}$ using AMV reverse transcriptase, we have never amplified cDNA with noncanonical intra-exons splicing. Despite all our efforts, we could not detect by RT-PCR, the mRNAs of $\Delta \mathrm{p} 53$ or of its theoretical spliced variant $\Delta \mathrm{p} 53 \beta, \Delta \mathrm{p} 53 \gamma, \Delta 133 \Delta \mathrm{p} 53, \Delta 133 \Delta \mathrm{p} 53 \beta$ and $\Delta 133 \Delta \mathrm{p} 53 \gamma$ in 21 normal human tissue analysed nor in numerous tumours of several human tissue origins. Several studies have already confirmed detection and abnormal expression of $\mathrm{p} 53 \beta, \mathrm{p} 53 \gamma, \Delta 133 \mathrm{p} 53, \Delta 133 \mathrm{p} 53 \beta$ and $\Delta 133 \mathrm{p} 53 \gamma$ in head and neck tumours (Boldrup et al, 2007), AML (Anensen et al, 2006) and in cell lines (Goldschneider et al, 2006). However, none of those studies reported detection of the $\Delta \mathrm{p} 53$ mRNA, although the primers used would have allowed its amplification by PCR.

Then, Rohaly et al (2005), attempt to demonstrate endogenous $\Delta \mathrm{p} 53$ protein expression using a panel of p53 monoclonal antibodies, DO-1 (epitope 21-25 aa), ICA-9 (epitope 383-393 aa) and DO-12 whose epitope (256-270 aa) is lost in $\Delta$ p53 protein. The author could detect a p53 band at $45 \mathrm{kDa}$ with DO- 1 and ICA-9 antibodies but not with DO-12 antibody, which was interpreted as proving the expression of the $\Delta \mathrm{p} 53$ isoform. However, this should be interpreted with cautious, as we showed that $\mathrm{p} 53 \beta, \mathrm{p} 53 \gamma$ and $\Delta 40 \mathrm{p} 53$ migrate all at $45 \mathrm{kDa}$ (Bourdon et al, 2005). In our hand, we can detect $\mathrm{p} 53 \beta$, p53 $\gamma$ and $\Delta 40 \mathrm{p} 53$ at $45 \mathrm{kDa}$ with DO-12 antibody after long exposure. It is thus likely that Rohaly et al's (2005) experimental conditions were not optimised to detect the $45 \mathrm{kDa}$ band (i.e. short exposure, high antibody dilution,...). Therefore, the $45 \mathrm{kDa}$ band identified by Rohaly et al (2005) is probably composed of a mix of $\Delta \mathrm{p} 53, \mathrm{p} 53 \beta, \mathrm{p} 53 \gamma$ and $\Delta 40 \mathrm{p} 53$.

To further confirm that the $45 \mathrm{kDa}$ band is $\Delta \mathrm{p} 53$ isoform, Rohaly et al (2005) immunoprecipitated the $45 \mathrm{kDa}$ band using p53 antibody and analysed it by MALTI-TOF/MS mass spectrometry. The masses of the tryptic fragments obtained from MALTI-TOF/ MS were compared to the predicted p53 tryptic peptide map by peptide mass fingerprinting using database-matching procedure. 
Table I p53 isoform-specific antibodies

\begin{tabular}{|c|c|c|c|c|c|c|}
\hline \multirow[b]{2}{*}{ Epitope (aa) } & \multicolumn{4}{|c|}{ Mouse monoclonal } & \multicolumn{2}{|c|}{ Rabbit polyclonal } \\
\hline & DO-I/DO-7 (20-25) & $180 \mid(46-55)$ & DO-I $2(256-270)$ & $421(372-382)$ & KJC8 $(\beta)$ & CMI recomb p53 \\
\hline p53 $\beta$ & ++ & ++ & + & - & ++ & ++ \\
\hline p53y & ++ & ++ & + & - & - & ++ \\
\hline$\Delta 40 p 53$ & - & ++ & + & - & - & ++ \\
\hline$\Delta 40 p 53 \beta$ & - & ++ & + & - & ++ & ++ \\
\hline$\Delta 133 p 53 \beta$ & - & - & ++ & - & ++ & + \\
\hline$\Delta 133 p 53 \gamma$ & - & - & ++ & - & - & + \\
\hline
\end{tabular}

The corresponding tryptic map assembled after MALDI-TOF/MS covered $88 \%$ of the p53 protein sequence, confirming that the $45 \mathrm{kDa}$ band is composed of p53 protein. The same tryptic fragments that did not match full-length $\mathrm{p} 53$, are encountered in the predicted $\Delta \mathrm{p} 53$ tryptic peptide map, but are also encountered in a mix of the predicted $\mathrm{p} 53 \beta$ and $\Delta 40 \mathrm{p} 53$ tryptic peptide maps. As the authors did not sequence the corresponding peptides, it is thus impossible to establish whether $\Delta \mathrm{p} 53$ is expressed. Only an antibody specific to $\Delta \mathrm{p} 53$ would prove unequivocally the endogenous expression of $\Delta \mathrm{p} 53$.

$\Delta \mathrm{p} 53$, which lacks a conserved domain of p53 in the DNAbinding domain, was reported to be transcriptionally active toward some p53 target genes and to be critical for the intra-S phase checkpoint (Rohaly et al, 2005). Contrary to previous publication, Chan and Poon (2007) recently reported with strong experimental evidences that $\Delta \mathrm{p} 53$ isoform lacks intrinsic transcriptional activity and lacks dominant-negative activity toward full-length $\mathrm{p} 53$. This is probably because $\Delta \mathrm{p} 53$ is not imported into the nucleus and stay in the cytoplasm. Therefore, further studies will be required to establish expression of the endogenous $\Delta \mathrm{p} 53$ isoforms and its biological relevance.

\section{DETERMINATION OF p53 STATUS BY SEQUENCING}

The difficulty to link p53 mutation status to clinical outcome and cancer treatment can be explained by the fact that mutations of the p53 gene do not necessarily result in inactivation of p53 transcriptional activity (Kato et al, 2003; Iacopetta et al, 2006; Petitjean et al, 2007b). Hence, $60 \%$ of the mutations that can occur in the $p 53$ gene do not alter p53 transcriptional activity. Only $15 \%$ of the mutations lead to mutant p53 completely inactive in transactivation. In the remaining 25\%, mutants p53 present differential transcriptional activity. They can transactivate some promoters, but are completely inactive on others. It is therefore important to establish whether p53 mutation is correlated to loss of p53 function to determine accurately p53 status in clinical studies.

Moreover, p53 mutation analysis has to be re-evaluated in cancer in light of p53 isoform expression. p53 isoforms are encoded by exons different from full-length p53, mutations occuring upstream of codon 133 (exon-5) or downstream of codon 331 (exon-9), would affect some p53 isoforms, but not others. This may lead to the loss of some p53 biological activities, keeping others unaffected. Furthermore, although p53 gene mutated at codon 133 substituting methionine to valine, leucine or isoleucine encodes for a p53 protein with similar transcriptional activity to wild-type $\mathrm{p} 53$, such a mutation prevents initiation of translation and thus expression of $\Delta 133 \mathrm{p} 53, \Delta 133 \mathrm{p} 53 \beta$ and $\Delta 133$ p53 $\gamma$ isoforms (Kato et al, 2003; Iacopetta et al, 2006; Petitjean et al, 2007b). Similarly, mutations in introns of $p 53$ gene can alter p53 activity either by affecting alternative splicing or by altering the activity of the internal $p 53$ promoter located in intron
4. As p53 isoform can modulate p53 transcriptional activity and p53-mediated apoptosis, the ratio between p53 isoforms can be an important cell fate determinant. The changes upon stimuli of the balance and interactions between the isoforms are likely to be fundamental to our understanding in the transition between normal cell cycling and the onset of tumour formation.

\section{DETERMINATION OF p53 STATUS BY IMMUNOSTAINING}

p53 immunostaining on tumour sections should be interpreted with cautious, as commonly available p53 antibodies can detect some p53 isoforms, but do not identify them specifically (Table 1). The mouse monoclonal antibodies DO-1 and DO-7 recognise p53, $\mathrm{p} 53 \beta$ and $\mathrm{p} 53 \gamma$, but not the other $\mathrm{p} 53$ isoforms. The rabbit or sheep polyclonal p53 antibodies (CM1, $\mathrm{SaPu}$, respectively) raised against recombinant full-length human p53 protein recognise all p53 isoforms, although $\Delta 133 \mathrm{p} 53 \beta$ and $\Delta 133 \mathrm{p} 53 \gamma$ are weakly revealed by polyclonal antibodies as these isoforms have lost most immunogenic domains of $\mathrm{p} 53$. The mouse monoclonal antibody, 1801 , can reveal specifically most p53 isoforms except $\Delta 133 \mathrm{p} 53$, $\Delta 133 \mathrm{p} 53 \beta$ and $\Delta 133 \mathrm{p} 53 \gamma$. The mouse monoclonal antibody DO-12 has a weak affinity for p53 and requires a long exposure to reveal p53 isoforms. However, DO-12 is particularly efficient to immunoprecipitate $\Delta 133 \mathrm{p} 53, \Delta 133 \mathrm{p} 53 \beta$ and $\Delta 133 \mathrm{p} 53 \gamma$ isoforms, which can be revealed by CM1 rabbit polyclonal antibody. The 421 mouse monoclonal antibody has also a low affinity for p53 mostly, because its epitope can be heavily modified by phosphorylations, ubiquitinylation, acetylation, methylation and neddylation. Although the 421 epitope is present in $\Delta 40 \mathrm{p} 53$ and $\Delta 133 \mathrm{p} 53$ isoforms, we have never been able to detect these isoforms using the 421 antibody. The rabbit polyclonal KJC8 antibody is specific of $\mathrm{p} 53 \beta$ isoforms and can be used in paraffin-embedded tissue. Novel specific p53 isoforms antibodies are being generated and will allow a clear identification of the p53 isoforms in the near future.

p53 isoforms have different subcellular localisations. Therefore, the use of a panel of p53 antibodies in immunohistochemistry can give different staining patterns for $\mathrm{p} 53$ in a same tumour sample. It would be interesting to investigate whether some p53 subcellular localisation can be associated with clinical markers. To have a better understanding of p53 immunostaining, it should be completed by RT-PCR analysis to determine p53 isoform mRNA expression in tumours.

Detection of p53 isoform expression by RT-PCR requires highquality RNA. As RNAs are rapidly degraded in tissue in absence of blood supply (half-life of $15 \mathrm{~min}$ ), RNAs have to be extracted immediately after biopsies or after surgical resection or on tumour samples nitrogen-frozen immediately after surgical resection. After purification, only total RNA extracts presenting a suitable ratio $28 S / 18 S \geqslant 1.5$ should be used for RT-PCR to determine p53 isoform expression in tumours. Such RNA quality is very difficult to obtain 
from paraffin-embedded tumour section as paraffin treatment destroys low abundant mRNA. Therefore, it is not recommended to use paraffin-embedded sections as source of RNA for RT-PCR of p53 isoform.

Therefore, determination of p53 status in clinical studies is much more complex than hitherto appreciated. It suggests that it requires an integrated and complex analysis of p53 isoform expressions associated with p53 mutation analysis and immunohistochemistry. To date, no clinical studies have integrated all those p53 parameters to determine p53 status. Several clinical studies attempted to establish p53 status by analysing p53 target

\section{REFERENCES}

Anensen N, Oyan AM, Bourdon JC, Kalland KH, Bruserud O, Gjertsen BT (2006) A distinct p53 protein isoform signature reflects the onset of induction chemotherapy for acute myeloid leukemia. Clin Cancer Res 12: $3985-3992$

Boldrup L, Bourdon JC, Coates PJ, Sjostrom B, Nylander K (2007) Expression of p53 isoforms in squamous cell carcinoma of the head and neck. Eur J Cancer 43: 617-623

Bourdon JC, Deguin-Chambon V, Lelong JC, Dessen P, May P, Debuire B, May E (1997) Further characterisation of the p53 responsive element identification of new candidate genes for trans-activation by $\mathrm{p} 53$. Oncogene 14: 85-94

Bourdon JC, Fernandes K, Murray-Zmijewski F, Liu G, Diot A, Xirodimas DP, Saville MK, Lane DP (2005) p53 isoforms can regulate p53 transcriptional activity. Genes Dev 19: 2122-2137

Bouvard V, Zaitchouk T, Vacher M, Duthu A, Canivet M, Choisy-Rossi C, Nieruchalski M, May E (2000) Tissue and cell-specific expression of the p53-target genes: bax, fas, $\mathrm{mdm} 2$ and waf $1 / \mathrm{p} 21$, before and following ionising irradiation in mice. Oncogene 19: 649-660

Chan WM, Poon RY (2007) The p53 isoform Deltap53 lacks intrinsic transcriptional activity and reveals the critical role of nuclear import in dominant-negative activity. Cancer Res 67: 1959-1969

Chen J, Ruan H, Ng SM, Gao C, Soo HM, Wu W, Zhang Z, Wen Z, Lane DP, Peng J (2005) Loss of function of def selectively up-regulates Delta113p53 expression to arrest expansion growth of digestive organs in zebrafish. Genes Dev 19: 2900-2911

Chipuk JE, Green DR (2006) Dissecting p53-dependent apoptosis. Cell Death Differ 13: 994-1002

El-Deiry WS, Kern SE, Pietenpol JA, Kinzler KW, Vogelstein B (1992) Definition of a consensus binding site for p53. Nat Genet 1: 45-49

El-Deiry WS, Tokino T, Velculescu VE, Levy DB, Parsons R, Trent JM, Lin D, Mercer WE, Kinzler KW, Vogelstein B (1993) WAF1, a potential mediator of p53 tumor suppression. Cell 75: 817-825

Fei P, Bernhard EJ, El-Deiry WS (2002) Tissue-specific induction of p53 targets in vivo. Cancer Res 62: 7316-7327

Funk WD, Pak DT, Karas RH, Wright WE, Shay JW (1992) A transcriptionally active DNA-binding site for human p53 protein complexes. Mol Cell Biol 12: 2866-2871

Ghosh A, Stewart D, Matlashewski G (2004) Regulation of human p53 activity and cell localization by alternative splicing. Mol Cell Biol 24: 7987-7997

Goldschneider D, Horvilleur E, Plassa LF, Guillaud-Bataille M, Million K, Wittmer-Dupret E, Danglot G, de The H, Benard J, May E, Douc-Rasy S (2006) Expression of C-terminal deleted p53 isoforms in neuroblastoma. Nucleic Acids Res 34: 5603-5612. Epub 2006 Oct 5

Harper JW, Adami GR, Wei N, Keyomarsi K, Elledge SJ (1993) The p21 CdK-interacting protein Cip1 is a Potent inhibitor of G1 cyclindependent kinases. Cell 75: 805-816

Helton ES, Zhu J, Chen X (2006) The unique NH2-terminally deleted (DeltaN) residues, the PXXP motif, and the PPXY motif are required for the transcriptional activity of the DeltaN variant of p63. J Biol Chem 281: $2533-2542$

Iacopetta B, Russo A, Bazan V, Dardanoni G, Gebbia N, Soussi T, Kerr D, Elsaleh H, Soong R, Kandioler D, Janschek E, Kappel S, Lung M, Leung CS, Ko JM, Yuen S, Ho J, Leung SY, Crapez E, Duffour J, Ychou M, Leahy DT, O'Donoghue DP, Agnese V, Cascio S, Di Fede G, Chieco-Bianchi L, Bertorelle R, Belluco C, Giaretti W, Castagnola P, Ricevuto E, Ficorella C, Bosari S, Arizzi CD, Miyaki M, Onda M, Kampman E, Diergaarde B, Royds J, Lothe RA, Diep CB, Meling GI, Ostrowski J, Trzeciak L, gene expression either by immunostaining or RNA microarray. Unfortunately, there are no established gene or protein markers of p53 functional activity yet. However, one can expect that future studies will be able to identify some. It would simplify greatly the determination of p53 status in tumours and help to diagnosis and cancer treatment.

\section{ACKNOWLEDGEMENTS}

This work is supported by Cancer Research-UK.
Guzinska-Ustymowicz K, Zalewski B, Capella GM, Moreno V, Peinado MA, Lonnroth C, Lundholm K, Sun XF, Jansson A, Bouzourene H, Hsieh LL, Tang R, Smith DR, Allen-Mersh TG, Khan ZA, Shorthouse AJ, Silverman ML, Kato S, Ishioka C (2006) Functional categories of TP53 mutation in colorectal cancer: results of an International Collaborative Study. Ann Oncol 17: 842

Iwakuma T, Lozano G (2007) Crippling p53 activities via knock-in mutations in mouse models. Oncogene 26: 2177-2184

Kaghad M, Bonnet H, Yang A, Creancier L, Biscan JC, Valent A, Minty A, Chalon P, Lelias JM, Dumont X, Ferrara P, McKeon F, Caput D (1997) Monoallelically expressed gene related to p53 at 1p36, a region frequently deleted in neuroblastoma and other human cancers. Cell 90: 809-819

Kato S, Han SY, Liu W, Otsuka K, Shibata H, Kanamaru R, Ishioka C (2003) Understanding the function-structure and function-mutation relationships of p53 tumor suppressor protein by high-resolution missense mutation analysis. Proc Natl Acad Sci USA 100: 8424

Kops GJ, Weaver BA, Cleveland DW (2005) On the road to cancer: aneuploidy and the mitotic checkpoint. Nat Rev Cancer 5: 773-785

Lane DP (1992) Cancer. p53, guardian of the genome [news; comment] [see comments]. Nature 358: 15-16

Lozano G (2007) The oncogenic roles of p53 mutants in mouse models. Curr Opin Genet Dev 17: 66-70

Midgley CA, Owens B, Briscoe CV, Thomas DB, Lane DP, Hall PA (1995) Coupling between gamma irradiation, p53 induction and the apoptotic response depends upon cell type in vivo. J Cell Sci 108: 1843-1848

Mills AA, Zheng B, Wang XJ, Vogel H, Roop DR, Bradley A (1999) p63 is a p53 homologue required for limb and epidermal morphogenesis [in Process Citation]. Nature 398: 708-713

Moll UM, Wolff S, Speidel D, Deppert W (2005) Transcription-independent pro-apoptotic functions of p53. Curr Opin Cell Biol 17: 631-636

Murray-Zmijewski F, Lane DP, Bourdon JC (2006) p53/p63/p73 isoforms: an orchestra of isoforms to harmonise cell differentiation and response to stress. Cell Death Differ 13: 962-972

Petitjean A, Achatz MI, Borresen-Dale AL, Hainaut P, Olivier M (2007a) TP53 mutations in human cancers: functional selection and impact on cancer prognosis and outcomes. Oncogene 26: 2157-2165

Petitjean A, Mathe E, Kato S, Ishioka C, Tavtigian SV, Hainaut P, Olivier M (2007b) Impact of mutant p53 functional properties on TP53 mutation patterns and tumor phenotype: lessons from recent developments in the IARC TP53 database. Hum Mutat 20: 20

Rohaly G, Chemnitz J, Dehde S, Nunez AM, Heukeshoven J, Deppert W, Dornreiter I (2005) A novel human p53 isoform is an essential element of the ATR-intra-S phase checkpoint. Cell 122: 21-32

Stamm S, Ben-Ari S, Rafalska I, Tang Y, Zhang Z, Toiber D, Thanaraj TA, Soreq H (2005) Function of alternative splicing. Gene 344: 1-20

Stiewe T (2007) The p53 family in differentiation and tumorigenesis. Nat Rev Cancer 7: $165-168$

Vousden KH, Lane DP (2007) p53 in health and disease. Nat Rev Mol Cell Biol 8: $275-283$

Yang A, Kaghad M, Wang Y, Gillett E, Fleming MD, Dotsch V, Andrews NC, Caput D, McKeon F (1998) p63, a p53 homolog at 3q27-29, encodes multiple products with transactivating, death-inducing, and dominantnegative activities. Mol Cell 2: 305-316

Yang A, Walker N, Bronson R, Kaghad M, Oosterwegel M, Bonnin J, Vagner C, Bonnet H, Dikkes P, Sharpe A, McKeon F, Caput D (2000) p73-deficient mice have neurological, pheromonal and inflammatory defects but lack spontaneous tumours. Nature 404: 99-103 